A. O. Bondarenko ${ }^{1}$, Dr. Sc. (Tech.), Prof., orcid.org/0000-0002-7666-6752, R. P. Naumenko ${ }^{2}$, Cand. Sc. (Econ.), orcid.org/0000-0002-2796-1771
1 - Dnipro University of Technology, Dnipro, Ukraine, email: Bondarenkoa@nmu.org.ua

2 - Zhytomyr Regional State Administration, Zhytomyr, Ukraine, e-mail: r_naumenko@ukr.net

\title{
COMPREHENSIVE SOLUTION OF RECYCLING WASTE FROM STONE PROCESSING INDUSTRY
}

Purpose. Development of integrated technological solutions for utilization, accumulation and processing of wastes of the stone-processing industry with the production of marketable products with commercial value.

Methodology. Technological solutions have been applied for separate utilization, transportation, storage and processing of granular waste of the stone-processing industry in accordance with their initial size.

Findings. The technological rationality of separate delivery and warehousing to temporary warehouses in the form of storage pits no more than $2.5 \mathrm{~m}$ high (with site arrangement between them of large-scale waste rubbish and medium and small stone cuttings) by specialized dump trucks equipped with grabbing petrol buckets and dump-shaped reinforced bodies is substantiated. The technology of the preparation of oversized raw materials for further grinding using crushing equipment on a mobile chassis is described, using hydraulic hammers as a hydraulic excavator attachment. The rationality of the application of the technology for the collection, transportation and drainage of primary sludge by means of specialized automobile chassis-slurry trucks equipped with a mobile slurry container was substantiated. The peculiarities of two-stage processing of primary sludge i considered with the provision of their drainage first in Mobile Slurry Containers, then on secondary drainage sites and final cleaning from fine-dispersed impurities and the receipt of the commercial product in the form of artificial sand by washing. As a result of experimental and industrial testing and testing of the technology of the mobile slurry container filling, the technological rationality of the use of mobile slurry containers is determined.

Originality. For the first time, a technology of recycling and two-stage sequential processing of primary sludges, which are man-made waste of stone-making production with deriving a commercial product in the form of artificial sand, is developed.

Practical value. Research and industrial testing of the technology of the mobile slurry container filling with sludge with the subsequent washing of the drained granular material has been performed. The performed research studies allowed quantifying the technological rationality of two-stage processing of primary sludge using mobile slurry containers and gravity hydraulic classifiers.

Keywords: technological wastes, slurry, warehousing, processing, gravitational classification

Introduction. Non-metallic minerals are the most widespread in Ukraine both by the number of kinds and by the number of open and developed deposits. For stocks such as facing stone (granite, gabbro, labradorite, etc.), Ukraine is a leader in Europe. Non-metallic minerals have a fairly broad field of application in industry, construction, science and technology, home and medicine.

There are 444 facing and sawdust deposits on the territory of Ukraine, of which 187 are under development. The balance stocks of such raw materials only in categories $A, B, C_{1}$ make 1342 million $\mathrm{m}^{3}$, of which 434 million $\mathrm{m}^{3}$ are under development [1]. Most of these deposits are geologically linked to the Ukrainian crystalline shield, which extends almost $1000 \mathrm{~km}$ from the coast of the Azov Sea to the borders with Belarus and occupies more than a third of the country's territory.

Ukrainian granites are of high quality, durability, strength and frost resistance. In addition, domestic granites are valued in the world for their high decorative character, because they have a bright color scheme and structure.

One of the most significant mining regions of Ukraine is Zhytomyr Region, in which 190 deposits of mineral raw materials are developed. Some of them are quite unique. Thus, in the depths of the region more than $85 \%$ of all national reserves of quartzites, labradorites and gabbro are concentrated in more than 80 quarries. In turn, there is also a local industry for the processing of such a stone, which has about 1000 stone-processing enterprises. The technology of producing decorative products usually takes place in two stages. At the first stage, the blocks are sprayed by machines with a straightforward motion of the saw frame, as well as tape, disk and cable saws. At the second stage of processing, the surface of the stone is polished by powder coating tools, fabric and felt circles, chromium oxide paste. Circulating technological water supply is used for cooling stone tools and for removing sand and dust.

Such a complicated and quite labor-intensive processing of the stone leads to the formation of a significant amount of waste

(C) Bondarenko A. O., Naumenko R. P., 2019 which is stone booth, stone trimming and slurry in the form of a mixture of sand with fine-grained particles. According to various estimates, stone-processing enterprises, located on the territory of Zhytomyr Region, annually produce about 60 thousand $\mathrm{m}^{3}$ of man-made solid waste of stone booth and stone trimming and more than 50 thousand $\mathrm{m}^{3}$ of slurry [2]. At the same time, waste is uncontrollably disposed of without being orderly utilized and processed, which leads to significant pollution of the territories and violation of the ecological balance (Fig. 1).

Literature review. Over decades, dumping of such manmade waste from the stone-making process into the natural environment has turned the scenically attractive land into a territory of ecological disaster. For this purpose, in Zhytomyr, a specialized communal enterprise was established, whose main line of work is collection, acceptance, storage, processing of waste products at specialized landfills, and related services [3].

Unsolved aspects of the problem. The solution of the situation with the waste of stone processing in particular in Zhytomyr region and in general in the state is expedient only by developing and introducing technologies for warehousing and further processing of such mineral raw materials with deriving a marketable products with commercial value. The basic concept of the plan is to divide the work into two separate stages. The first stage is the development and implementation of technological solutions for transportation and separate storage of stone booth waste, medium and small stone cuttings, primary sludge [4]. At the second stage of conceptual technological solutions an organization of processing of man-made raw materials with deriving various classes of crushed stone and sand required by the domestic construction industry is provided [5].

Purpose. The purpose of the work is to develop complex technological solutions for the recycling, storage and processing of waste from the industry of stone processing with deriving marketable products with commercial value.

Methods. Technological solutions are applied for separate utilization, transportation, storage and processing of granular waste from the stone-processing industry in accordance with their primary size. 


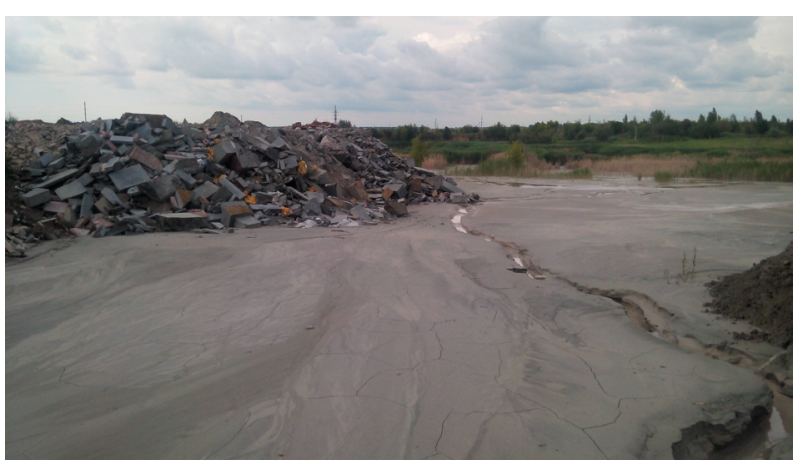

Fig. 1. An example of waste dumping from stone processing in Zhytomyr region

Results. Implementation of the first stage of the general concept of warehousing and further processing of man-made waste involves the use of specialized dump trucks equipped with grappling petrol buckets and dump-shaped reinforced bodies for loading, delivery and unloading of medium and small stone cuttings, as well as dump trucks, equipped with hook suspension brackets for loading, delivery and unloading of booth wastes. It is expedient to organize the storage of raw materials at the processing site in separate warehouses in the form of storage pits of not more than $2.5 \mathrm{~m}$ high with the organization of the working platform between them. This arrangement of warehouses will allow further preparing oversized raw materials, using hydraulic hammers as hinged equipment of a hydraulic excavator, and to bring the overall dimensions to allow further grinding using standard crushing equipment [5].

Slurry which can be a granular material of various sizes from 0 to $10 \mathrm{~mm}$, according to the traditional technology of stone processing, accumulates in the decanters of stone processing enterprises. For its transportation to the processing site, it is expedient to use specialized slurry trucks, which should include a loading and unloading mechanism and a mobile slurry container to be completed on the basis of the car chassis [6]. A mobile slurry container is a vessel, which consists of external and internal bodies. The internal body is made of a steel sheet with holes or a grid on the inner surface of which it is possible to install and replace the filter fabric. The external body is made of fittings in the lower part of the unit, which provide drainage of slurry water outwards and dewatering of the sludge in the internal body. Sewage vacuum machines, for example KO $503 \mathrm{~V}$, can also be used to deliver slurries.

The technology of storing slurries involves their delivery from the places of collection by a specialized slurry carrier. After delivery, the mobile slurry container is removed from the chassis carrier platform and is set up on the territory of the predrainage area where it is located before the completion of the previous drainage of the primary sludge. In the case of removal and delivery of sludge to the site with a sewage vacuum machine, the sludge is merged into the mobile slurry container which is installed on the site of the preliminary drainage (Fig. 2). The process of preliminary drainage is considered complete in the absence of leakage of liquid slurry from drainage nozzles of the mobile slurry container. The next stage of drainage of slurries is the unloading of pre-dewatered primary sludge from the mobile slurry container to the secondary drainage site of the primary sludge (Fig. 2). The discharge of sludge is carried out with the help of a specialized slurry carrier.

After drainage on the secondary drainage site, primary sludges are developed by the complex front wheel loader - dump truck with delivery to the warehouse of dehydrated sludge.

Sites of primary and secondary drainage of sludges are located near the pool for cleaning slurry water [7]. Drainage sites are organized in such a way that liquid slurry is able to get into the pool by gravity. The pool consists of two tanks separated by a wall. One tank is provided for the accumulation of liquid slur-

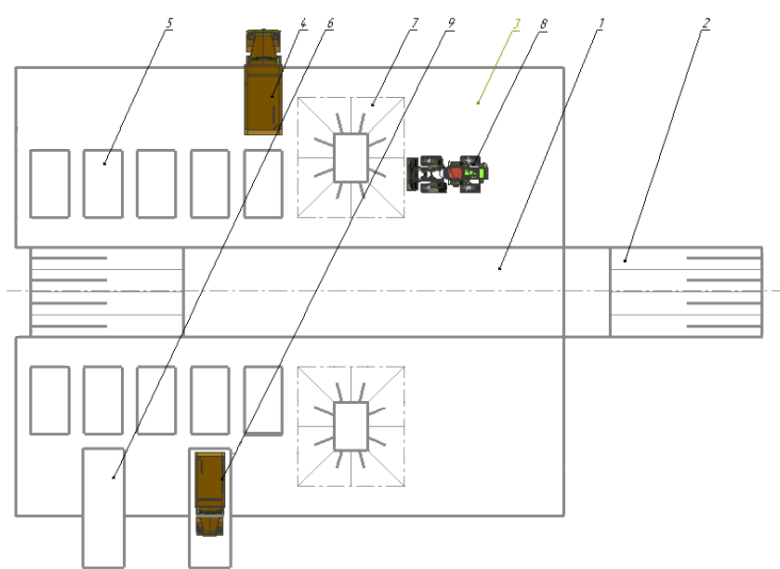

Fig. 2. Location of the elements of the complex for drainage of primary sludge and illumination of sludge waters:

1 - capacity of rough cleaning; 2 - sink hole; 3 -drainage site; 4 - purpose-built slurry carrier; 5 - mobile slurry container; $6-$ ramp; 7-temporary warehouse of primary sludge; 8 - front wheel loader; 9 - sewage vacuum machine

ries formed after the primary and secondary drainage of sludge, the second capacity - a sink hole is provided for the accumulation of lit up water. The specified wall has a height less than the height of the sides of the pool to ensure the flow of lit water from the tank to accumulate liquid slurry to the capacity of the accumulation of illuminated water. The lighted slurry water is subsequently taken out by a sewage vacuum machine or a purpose-built slurry carrier for stone processing enterprises to feed the circulating technological water supply. The approximate location of the elements of the complex for drainage of primary sludge and cleaning of slurry waters is shown in Fig. 2.

Such a technology of accumulation and drainage of sludge provides for the alternate filling and cleaning of the capacity of the pool for rough cleaning (Fig. 2). When cleaning the pool, work on the delivery of sludge must be stopped. Front wheel loaders, grabbing excavators, back shovels and draglines can be used to clean the decanter from precipitated fine dispersed sludge, with subsequent delivery by dump trucks and storage to a separate warehouse.

At the second stage of conceptual technological solutions an organization of processing of man-made raw materials with deriving various classes of crushed stone and artificial sand is foreseen. When choosing crushing and sorting equipment it is necessary to take into account information concerning the strength characteristics of the raw material. The material composition, technological properties, physical and mechanical characteristics of the local mineral raw material, which is the source for the formation of waste as a result of its treatment at stone processing enterprises of Zhytomyr region, can be attributed to the first type (solid homogeneous abrasive rocks) and the first group - igneous rocks (granites, diorites, sienites, basalts, etc.) with a compression strength of $800-2500 \mathrm{kgf} / \mathrm{cm}^{2}$ and more, pure or slightly contaminated by dusts inclusions. For their processing in accordance with [5] a technological scheme with the crushing of raw materials in jaw and cone crushers, preliminary and checking screening is recommended. Two-stage crushing of raw materials is also acceptable.

One of the possible variants of technology for processing man-made raw wastes materials, which is annually produced by the stone-processing enterprises of Zhytomyr region in the amount of about 60 thousand $\mathrm{m}^{3}$, is the use of a mobile crushing and sorting complex, which includes vibrating feeder, jaw and cone crushers, vibrating screen and belt conveyors installed on the power support chassis. Loading to the receiving hopper of the crusher is carried out by front wheel loaders or hydraulic excavators with mandatory control of the sizes of raw materials which should not exceed the limiting sizes for 
the processing of raw materials by a specific type of crusher in accordance with its technical characteristics. After crushing and sorting, the marketable products are transported to the temporary cone warehouses with the conveyor equipment of the complex. After that, the marketable products is delivered and stored to separate temporary cone warehouses in accordance with their classes by means of front wheel loaders.

Sludge processing requires more detailed and deep work. One of the types of products that can be obtained during the processing of sludge by washing them is artificial construction sand [8]. However, sludge is characterized by significant contamination by fine and dusty classes. For example, in studying the granulometric composition of sludge, the percentage of sand larger than $0.1 \mathrm{~mm}$ was only $38.5 \%$ (Table). Such a significant content of finely dispersed and dusts classes in the source product requires the washing of the granular material in two or even three stages [9]. Therefore, the processing of the contaminated primary sludge is unlikely to be economically feasible without preliminary preparation, which can be performed by filtration and drainage of sludge in the mobile slurry containers.

In order to determine the technological rationality of using mobile slurry containers in the summer of 2018, on the basis of the stone processing plant in Zhytomyr region, experimental and industrial testing of the technology for filling of the mobile slurry container with slurry was carried out. For this purpose, a test model of a mobile slurry container (Fig. 3) was developed and manufactured, which is a metal box made in the form of a frame construction with a metal net. The model has an open top and doors, which are locked by a latch. Internal dimensions of the mobile slurry container model are: length-$1000 \mathrm{~mm}$, width $-500 \mathrm{~mm}$, height $-900 \mathrm{~mm}$; external dimensions are: length $1100-\mathrm{mm}$, width $630-\mathrm{mm}$, height $1070 \mathrm{~mm}$. In order to ensure the filtration and accumulation of primary sludge in a pre-formed vessel, a sack made of a filter fabric for vacuum filters was installed and secured (Fig. 4).

The testing of technology for filling the mobile slurry container with primary sludge was carried out in the following sequence. The test model of the mobile slurry container with the help of a car crane was installed near the decanter of the stoneprocessing plant. The submersible pump SP20 was deepened to a layer pre-deposited in the primary sludge decanter. A portable pumping station for feeding the hydraulic submersible pump was turned on. A slurry containing primary sludge was supplied by a fire hose to a model of the mobile slurry container with a filter net installed (Fig. 4). Visual observation of the process was performed and the time was controlled of fill- ing the capacity of the mobile slurry container model with sludge and drainage of liquid slurry to the decanter using a stopwatch. In the case of slogger the holes of the filter fabric with fine sludge particles, mechanical cleaning of the fabric was performed using a floor brush. The obtained values were entered into the research journal. The process of feeding the pulp was stopped after filling up the capacity of the mobile slurry container with sludge. The work of the pumping station was stopped. The cycle of the experiment was completed by overturning the model of the mobile slurry container using a truck crane and removing the sludge from the capacity to the decanter. The angle of the bottom of the mobile slurry container model at which the sludge was discharged was fixed. Samples of sludge were collected. The state of the design of the mobile slurry container and the bag made of a filter fabric were monitored. The model of the mobile slurry container was installed for the next measurement. The cycle of experiments was repeated five times. To perform the necessary measurements such standard equipment was also used: truck crane with mast arrow; hydraulic submersible pump SP20; pumping station of a hydraulic drive portable; nylon fire hose $\varnothing 51 \mathrm{~mm}$ from GR-50 DSTU 3810-98; stopwatch "Agat" with a discretion of $0.5 \mathrm{~s}$; filter fabric for vacuum filters with holes of $0.23 \cdot 0.35 \mathrm{~mm}$ and $0.15 \cdot 0.25 \mathrm{~mm}( \pm 0.02)$ TUU 00306800.001-96; tape measuring metal DSTU 4179-2003; protractor NO5001.

Experimental-industrial tests showed that after dewatering as a result of filling the model of the mobile slurry container, the granular material that is filtered through the filter fabric becomes larger. The percentage of sand larger than $0.16 \mathrm{~mm}$ after drainage in the model of the mobile slurry container was $81.1 \%$ (Table). The content of grains which passed through the sieve of $0.16,0.1,0.05 \mathrm{~mm}$ were $18.9,13.15,6.93 \%$ by weight. According to the information on the modern technologies used for the washing of granular materials, obtaining high-quality construction sand from the specified initial product is quite possible. To this purpose, it is advisable to use the domestic innovative technology of granular materials washing, developed by Professor Bondarenko A. O. [8, 9].

To confirm the possibility of using the indicated innovation technology, on the basis of the laboratory of hydromechanization and processing of mineral raw materials of the Dnipro University of Technology, laboratory studies of washing the primary sludge were conducted. In the course of studies using a laboratory installation Turbowasher, several averaged sludge compositions were washed out $[8,9]$. Characteristic for the further application of the technology is the composition of the sludge

Table

The granulometric composition

\begin{tabular}{|c|c|c|c|c|c|c|}
\hline \multirow[t]{2}{*}{ Size, $\mathrm{mm}$} & \multicolumn{2}{|c|}{ Primary sludge } & \multicolumn{2}{|c|}{$\begin{array}{c}\text { The sludge after filtration in a model } \\
\text { of the mobile slurry container }\end{array}$} & \multicolumn{2}{|c|}{$\begin{array}{l}\text { Grain material after washing in the } \\
\text { laboratory installation Turbowasher }\end{array}$} \\
\hline & yield, \% & $\Sigma, \%$ & yield, $\%$ & $\Sigma, \%$ & yield, \% & $\Sigma, \%$ \\
\hline$>5$ & 0 & 0 & 0 & 0 & 0 & 0 \\
\hline $2.5-5$ & 0.04 & 0.04 & 0.00 & 0.00 & 0.00 & 0.00 \\
\hline $1.8-2.5$ & 0.14 & 0.19 & 0.17 & 0.17 & 0.67 & 0.67 \\
\hline $1-1.8$ & 0.19 & 0.37 & 0.53 & 0.70 & 3.01 & 3.68 \\
\hline $0.63-1$ & 2.32 & 2.69 & 9.56 & 10.26 & 13.38 & 17.06 \\
\hline $0.5-0.63$ & 2.84 & 5.53 & 14.51 & 24.76 & 11.37 & 28.43 \\
\hline $0.4-0.5$ & 2.69 & 8.23 & 12.36 & 37.12 & 12.71 & 41.14 \\
\hline $0.315-0.4$ & 4.35 & 12.57 & 19.47 & 56.59 & 17.06 & 58.19 \\
\hline $0.2-0.315$ & 7.19 & 19.76 & 17.75 & 74.34 & 23.41 & 81.61 \\
\hline $0.16-0.2$ & 8.76 & 28.52 & 6.75 & 81.10 & 8.03 & 89.63 \\
\hline $0.1-0.16$ & 9.92 & 38.45 & 5.75 & 86.85 & 5.02 & 94.65 \\
\hline $0.05-0.1$ & 34.13 & 72.58 & 6.23 & 93.07 & 5.35 & 100.00 \\
\hline$<0.05$ & 27.42 & 100.00 & 6.93 & 100.00 & 0.00 & 100.00 \\
\hline Amount & 100.00 & $d_{a v}=0.15 \mathrm{~mm}$ & 100.00 & $d_{a v}=0.37 \mathrm{~mm}$ & 100 & $d_{a v}=0.43 \mathrm{~mm}$ \\
\hline
\end{tabular}




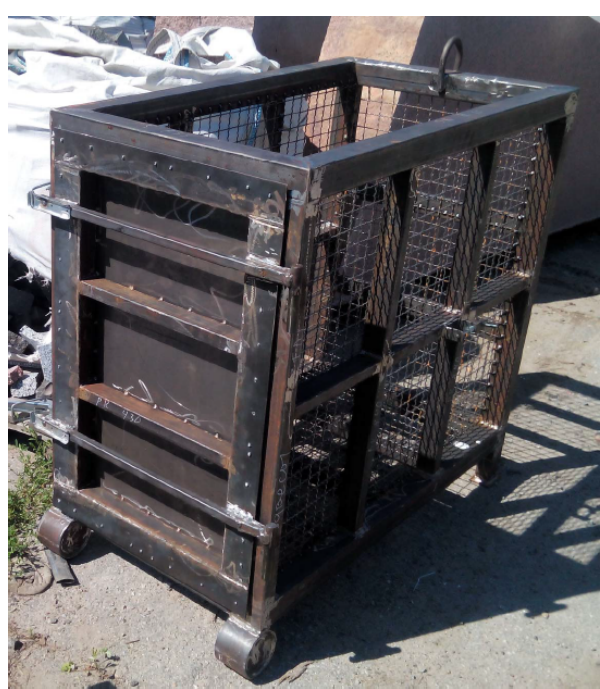

Fig. 3. General view of the test model of the mobile slurry container

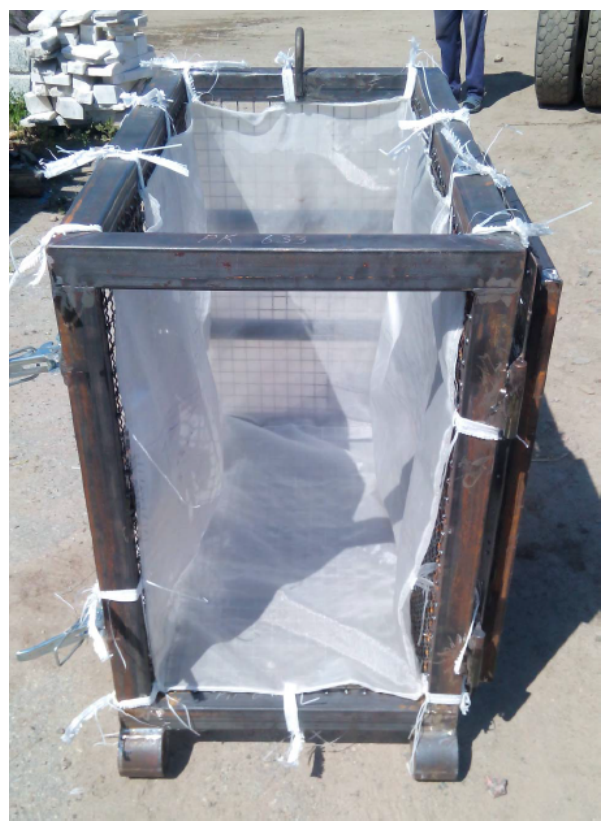

Fig. 4. Model of the mobile slurry container with a set up filter fabric bag

obtained after filtration and drainage in the model of the mobile slurry container based on the results of experimental and industrial tests of its test model. The granulometric composition of the granular material obtained after filtration in a model of the mobile slurry container and after washing it in the laboratory installation Turbowasher is given in the table. Graphical analysis of granulometric composition is shown in Fig. 5.

From the graphs, it is seen that after filtration in a model of the mobile slurry container and washing in the laboratory installation Turbowasher, the grain material has become considerably larger. For example, if the percentage of sand greater than 0.1 $\mathrm{mm}$ in the primary sludge was $38.5 \%$, then after washing it was $89.63 \%$. This affected the mean grain size of the granular material, which was $0.15 \mathrm{~mm}$ in the primary sludge, and after filtering and washing it was $0.43 \mathrm{~mm}$. If the number of finely dispersed grains smaller than $0.05 \mathrm{~mm}$ in the raw material was $27.42 \%$, after filtration and washing, traces of this class were found.

Generally, the technology of procession of stone booth and sludge wastes includes the delivery and separate storage of booth waste 1 and medium and small stone cuttings 2 with the help of specialized dump trucks 3 , the formation of warehouses in the form of storage pits with the use of front wheel load-

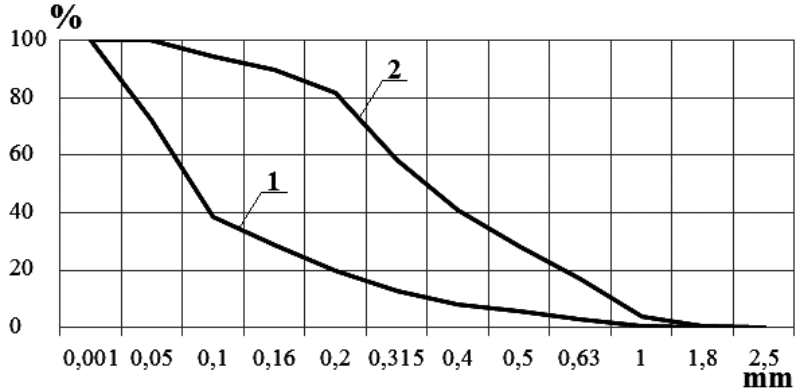

Fig. 5. The granulometric composition:

1 - primary sludge; 2 - sludge after filtration in a model of the mobile slurry container and washing in the laboratory installation Turbowasher

ers 4 , preliminary processing of stone booth by a hydraulic hammer, mounted as a hinged equipment for a hydraulic backhoe 5 , delivery of prepared raw materials, medium and small stone cuttings to the site of processing and loading into the hopper of the crushing and sorting complex 6 (Fig. 6). The received commodity products from temporary warehouses, which are formed by belt conveyors of the crushing and sorting complex, by front wheel loaders are delivered and unloaded into separate warehouses 7, 8, 9 for shipment to consumers or further processing. Primary sludges are delivered by purposebuilt slurry carriers 10 , after which the mobile slurry containers 11 are removed from the chassis and installed at drainage sludge sites 12 that are located at the pool for cleaning of slurry waters 13 . After cleaning, technological water accumulates in the sink hole of the pool 14 , and with the help of sewage vacuum machine 15 it is taken out to feed the technological recycling water supply systems of stone processing enterprises. When delivering slurry by means of sewage vacuum machines, it is drained into separately installed mobile slurry containers. After filtration and drainage of sludge in the mobile slurry containers, it is discharged to the temporary storage of sludge 16 , and then mined and delivered to the primary sludge warehouses 17 . Washing of primary sludge and screenings after crushing of stones is carried out on a separate complex for washing of granular materials Turbowasher 18 , which is located near the decanter 19 , which is used for lighting of technological water and organization of circulating water supply [10]. Losses of technological water are compensated by feeding up to the sink hole of decanter 20 water from a distant unlimited source of water supply [11]. The sand resulting after washing is stored to the temporary warehouse 21 and afterwards to the warehouse 22 , rubbish and gravel grades with a grain size of more than $5 \mathrm{~mm}$ first to the temporary warehouse 23 and afterwards to the warehouse 24 . In some cases, belt conveyors can be used to store mineral raw materials $[12,13]$. Over time, the decanter is slogged with finely divided sludge and requires cleaning which is carried out with front wheel loaders or excavators, the fine sludge are first stored in temporary warehouses located on the drainage site 25 and then into fine dispersed sludge warehouse 26 . In order to prevent access to the site by unauthorized persons, it is fenced with soil storage pits 27 (Fig. 6).

Conclusions. As a result of the performed research studies, the technological rationality of separate delivery, storage and further processing of man-made raw materials according to its initial size is substantiated. The expediency of two-stage processing of primary sludges with the provision of their drainage first in the mobile slurry containers, then in the secondary drainage sites and the final cleaning from fine dispersed impurities and deriving of the marketable product in the form of artificial sand by means of washing using gravity hydraulic classifiers was substantiated. Mineral properties of such commodity products allow its wide use in construction and other industries [14, 15].

Project name and number, in which the obtained results are presented. The work is associated to the scientific direction of 


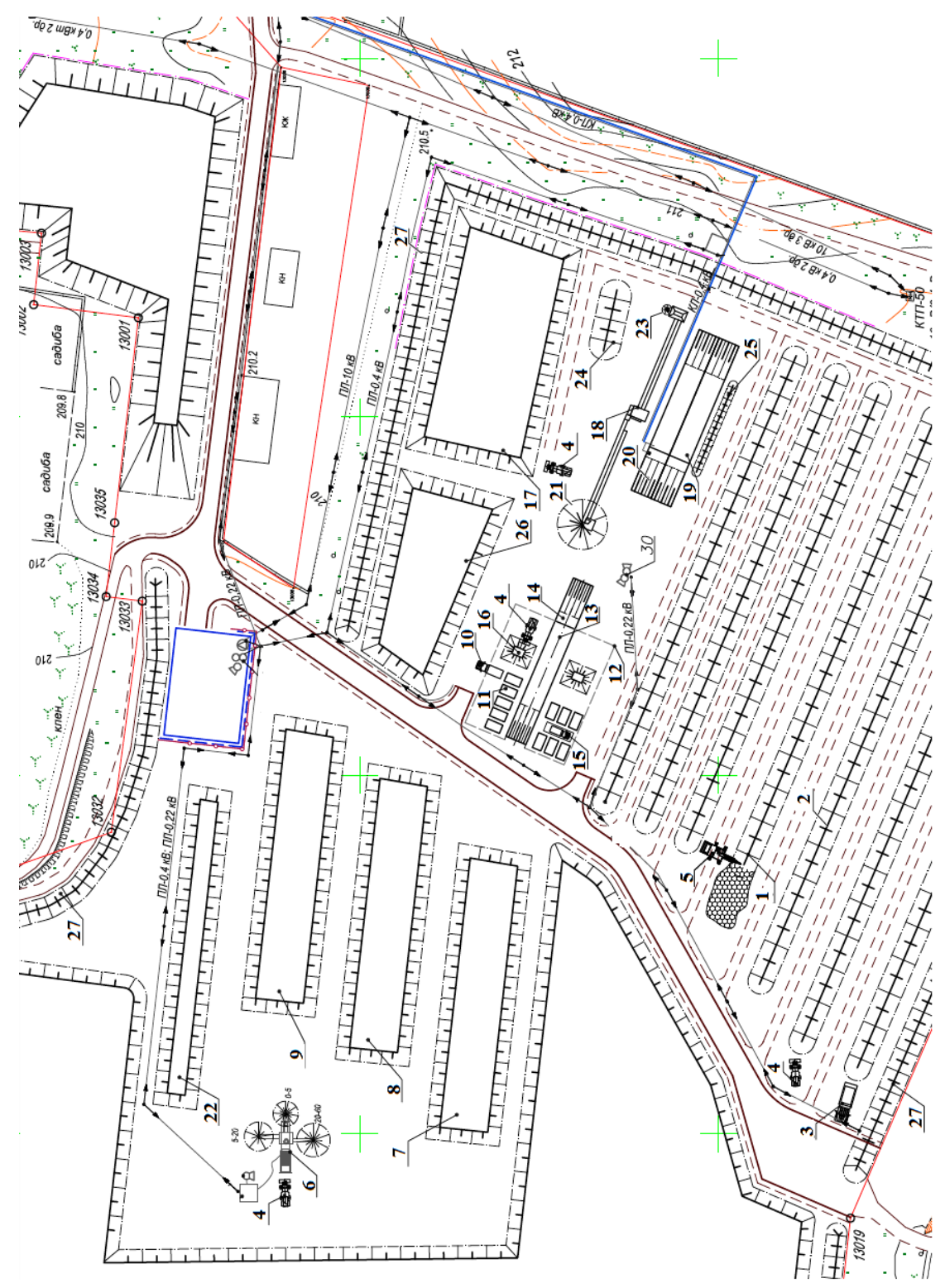

Fig. 6. Technological scheme of processing of booth waste and sludge

the Mining Machines and Engineering Department of the National TU Dnipro Polytechnic and is based on the results of the development of "Conceptual technological solutions of the site for the collection and primary processing of waste of stone processing industry in Korostyshiv district of Zhytomyr region".

\section{References.}

1. State Research and Development enterprise "State Information Geological Fund of Ukraine" (n.d.). Mineral Resources of Ukraine. Non-metallic mineral resources for construction. Retrieved from http://geoinf.kiev.ua.

2. Bobovich, B. B., \& Deviatkin, V. V. (2000). Processing wastes from production and consumption: reference book. Moscow: Intemet Engineering. Retrieved from https://www.twirpx.com/ file/871095.

3. Konev, V. (2013, April 17). Glare of ilmenite and poverty of Zhytomershchyna. Ekho. Zhytomyr Region social and business newspaper.

4. Nadutyi, V., Tytov, O., \& Cheberiachko, I. (2018). Hereditary model of loose mined rock layer deformation in disintegrators. In Ukrainian School of Mining Engineering E3S Web Conf., 60. DOI: 10.051/e3sconf/20186000033.

5. DPI Kryvbasproekt (2013). СОУ-Н МПП 73.020-0783:2013 norms of technological design of mining enterprises with open-pit mining. Retrieved from http://online.budstandart. com/ua/catalog/doc-page?id_doc $=66948$.

6. Jamil, S.H., Sukharyev, V.V., \& Kostyrya, S.V. (2015). Complex Dehydration of the Rock Mass. International Journal of Engineering and Science, 5(9), 7-10.

7. Bondarenko, A. A. (2018). Theoretical bases of pulp suction process in the shallow dredge underwater face. Naukovyi Visnyk Natsionalnoho Hirnychoho Universytetu, 3, 22-29. DOI: 10.29202/nvngu/2018-3/4.

8. Bondarenko, A.A. (2018). Modeling of interaction of inclined surfaces of a hydraulic classifier with a flow of solid particles. Naukovyi Visnyk Natsionalnoho Hirnychoho Universytetu, 4, 13-20. DOI: 10.29202/nvngu/2018-4/5.

9. Franchuk, V.P., \& Bondarenko, A.A. (2016). Horizontal classifiers. Fundamentals of theory and calculation. Dnipro: National mining university.

10. Bliuss, B. A., Semenenko, Ye. V., Medvedeva, O. A. (2016) Technology of reconstruction of accumulating capacity of enrichment rejects storages. Modern resource-energy-saving technology of mining, 1(17), 72-80.

11. Bliuss, B.A., Semenenko, Ye.V., \& Medvedeva, O.A. (2017). Methods for managing parameters of technogenic deposits while warehousing thick pulps of enrichment rejects. Modern resource-energy-saving technology of mining, 2(20), 71-80. 
12. Kolosov, D., Dolgov, O., \& Kolosov, A. (2014). Analytical determination of stress-strain state of rope caused by the transmission of the drive drum traction. In Progressive Technologies of Coal, Coalbed Methane, and Ores Mining (pp. 499-504).

13. Kolosov, D., Dolgov, O., Bilous, O., \& Kolosov, A. (2015). The stress-strain state of the belt in the operating changes of the burdening conveyor parameters. In New Developments in Mining Engineering 2015: Theoretical and Practical Solutions of Mineral Resources Mining (pp. 585-590).

14. Pivnyak, G., Samusia, V., Oksen, Y., \& Radiuk, M. (2014). Parameters optimization of heat pump units in mining enterprises. In Progressive Technologies of Coal, Coalbed Methane, and Ores Mining (pp. 19-24).

15. Iljin, S., Samusya, V., Iljina, I., \& Iljina, S. (2015). Influence of dynamic processes in mine winding plants on operating safety of shafts with broken geometry. In New Developments in Mining Engineering 2015: Theoretical and Practical Solutions of Mineral Resources Mining (pp. 425-429).

\section{Комплексне вирішення питання переробки відходів каменеобробного виробництва}

\section{А. О. Бондаренко ${ }^{1}$, Р. П. Науменко ${ }^{2}$}

1 - Національний технічний університет „Дніпровська політехніка“, м. Дніпро, Україна, e-mail: Bondarenkoa@ nmu.org.ua

2 - Житомирська обласна державна адміністрація, м. Житомир, Україна, e-mail: r_naumenko@ukr.net

Мета. Розробка комплексних технологічних рішень утилізації, накопичення й переробки відходів каменеобробної промисловості з отриманням товарної продукції, що має комерційну цінність.

Методика. Застосовані технологічні рішення роздільної утилізації, транспортування, складування й переробки зернистих відходів каменеобробної промисловості у відповідності до їх первинної крупності.

Результати. Обгрунтована технологічна раціональність окремої доставки та складування до тимчасових складів у вигляді буртів висотою не більше 2,5 м (3 організацією робочої площадки між ними великогабаритних бутових відходів і середньої й дрібної кам'яної обрізі) спеціалізованими автосамоскидами, обладнаними грейферними пелюстковими ковшами й самоскидними посиленими кузовами. Описана технологія підготовки негабаритної сировини до подальшого подрібнення з використанням дробильного устаткування на мобільному шасі, шляхом використання гідравлічних молотів у якості навісного обладнання гідравлічного екскаватора. Обгрунтована доцільність застосування технології збирання, транспортування й дренування первинних шламів за допомогою спеціалізованих автомобільних шасі-шламовозів, обладнаних зйомним бункером-шламовозом. Розглянуті особливості двостадійної переробки первинних шламів із забезпеченням їх дренування спочатку у бункерах-шламовозах, а потім на ділянках вторинного дренування й фінальним очищенням від дрібнодисперсних домішок та отриманням товарного продукту у вигляді штучного піску шляхом промивання. У результаті дослідно-промислових випробувань і тестування технології заповнення бункерашламовоза шламом визначена технологічна раціональність використання бункерів-шламовозів.

Наукова новизна. Уперше розроблена технологія утилізації та двостадійної послідовної переробки первинних шламів, що $є$ техногенними відходами каменеобробного виробництва, з отриманням товарного продукту у вигляді штучного піску.

Практична значимість. Виконані дослідно-промислові випробування й тестування технології заповнення бункера-шламовоза шламом 3 подальшим промиванням дренованого зернистого матеріалу. Виконані дослідження дозволили кількісно обгрунтувати технологічну раціональність двостадійної переробки первинних шламів 3 використанням бункерів-шламовозів і гравітаційних гідравлічних класифікаторів.

Ключові слова: техногенні відходи, илам, складування, переробка, гравітаційна класифікація

\section{Комплексное решение вопроса переработки отходов камнеобрабатывающего производства}

\section{А. А. Бондаренко ${ }^{1}$, Р. П. Науменко ${ }^{2}$}

1 - Национальный технический университет „Днепровская политехника“, г. Днепр, Украина, e-mail: Bondarenkoa@nmu.org.ua

2 - Житомирская областная государственная администрация, г. Житомир, Украина, e-mail: r_naumenko@ukr.net

Цель. Разработка комплексных технологических решений утилизации, накопления и переработки отходов камнеобрабатывающей промышленности с получением товарной продукции, имеющей коммерческую ценность.

Методика. Применены технологические решения раздельной утилизации, транспортирования, складирования и переработки зернистых отходов камнеобрабатывающей промышленности в соответствии с их первоначальной крупностью.

Результаты. Обоснована технологическая рациональность отдельной доставки и складирования на временные склады в виде буртов высотой не более 2,5 м (с организацией рабочей площадки между ними крупногабаритных бутовых отходов, средней и мелкой каменной обрези) специализированными автосамосвалами, оборудованными грейферными лепестковыми ковшами и самосвальными усиленными кузовами. Описана технология подготовки негабаритного сырья к дальнейшему дроблению с применением дробильного оборудования на мобильном шасси, путем использования гидравлических молотов в качестве навесного оборудования гидравлического экскаватора. Обоснована рациональность применения технологии сбора, транспортирования и дренирования первичных шламов с применением специализированных автомобильных шасси-шламовозов, оборудованных съемным бункером-шламовозом. Рассмотрены особенности двухстадийной переработки первичных шламов с обеспечением их дренирования сначала в бункерах-шламовозах потом на участках вторичного дренирования и финальной очисткой от мелкодисперсных примесей с получением товарного продукта в виде искусственного песка путем промывания. В результате опытно-промышленных испытаний и тестирования технологии заполнения бункерашламовоза шламом определена технологическая рациональность применения бункеров-шламовозов.

Научная новизна. Впервые разработана технология утилизации и двухстадийной последовательной переработки первичных шламов, являющихся техногенными отходами камнеобрабатывающего производства с получением товарного продукта в виде искусственного песка.

Практическая значимость. Выполнены опытно-промышленные испытания и тестирование технологии заполнения бункера-шламовоза шламом с дальнейшим промыванием дренированного зернистого материала. Выполненные исследования позволили количественно обосновать технологическую рациональность двухстадийной переработки первичных шламов с применением бункеров-шламовозов и гравитационных гидравлических классификаторов.

Ключевые слова: техногенные отходы, шлам, складирование, переработка, гравитационная классификация

Рекомендовано до публікації докт. техн. наук В. І. Симоненком. Дата надходження рукопису 27.06.18. 